\title{
STAREA DE HIPNOZĂ ÎN DREPTUL PENAL

\author{
SUBSTANȚIAL AL REPUBLICII MOLDOVA
}

DOI: 10.24193 /SUBBiur.65(2020).2.4

Data publicării online:

31.07 .2020

\section{Stela Botnaru; Ecaterina Șaporda*}

Rezumat: În acest articol vom analiza starea de hipnoză din perspectiva dreptului penal. Totodată este abordată hipnoza, că starea psihologică specială, și legătura acesteia cu instituțiile dreptului penal. Analiza starea de hipnoză va fi realizată sub două aspecte. Î́n primul rând, vom analiza problemele ce se referă la calificarea infracțiunii săvârșite asupra unei persoane hipnotizate. În cazul dat, hipnoza va fi privită în calitate de metodă de săvârșire a infracțiunii. În al doilea rând, ne-am propus să analizăm încadrarea juridico-penală a stării de hipnoză în cazul comiterii infracțiunii de către o persoană hipnotizată. Dat fiind faptul, că în dreptul penal actual lipsește încadrarea clară a stării de hipnoză, s-au conturat două opinii diferite, referitoare la aspectul dat, potrivit cărora aceasta reprezintă o stare de iresponsabilitate sau o formă de manifestare a constrângerii psihice aplicată asupra celui care comite fapta prejudiciabilă. Tema respectivă necesită o abordare aprofundată deoarece în practică astfel de cazuri se întâlnesc tot mai frecvent, iar lacunele legislative, în sensul dat, creează dificultăți. La final, vom veni și cu unele propuneri de lege-ferenda în legislația din Republica Moldova.

* Conf. Univ. Dr. Stela Botnaru, Prodecan al Facultății de Drept al Universității de Stat din Moldova, stelacorlateanu@gmail.com; Ecaterina ŞAPORDA, studentă în cadrul Facultăţii de Drept a Universității de Stat din Moldova, eshaporda@gmail.com.

\section{3}


Cuvinte-cheie: hipnoză, infracțiune, starea de iresponsabilitate, constrângerea psihică, metodă de săvârșire a infracțiunii.

\title{
HYPNOSIS IN THE CRIMINAL LAW OF THE REPUBLIC OF MOLDOVA.
}

\begin{abstract}
This article presents the analysis of the state of hypnosis from the aspect of criminal law. At the same time, it is approached the hypnosis as the special psychological state and its tangency with the institutions of criminal law. In this study, the state of hypnosis will be analyzed under two aspects. First, we will analyze the issues related to the qualification of the crime committed against a hypnotized person. In this case, hypnosis will be seen as a method of committing the crime. Secondly, we aimed to analyze the legal-criminal classification of the state of hypnosis in case of committing the crime by a hypnotized person. Since the current criminal law lacks a precise classification of the state of hypnosis, under this aspect, there are two different opinions regarding their legal classification: the state of irresponsibility or a form of mental coercion. This issue requires an in-depth approach, for the reason that in practice, such cases are encountered more and more often, and legislative gaps, in this sense, create difficulties.
\end{abstract}

Key-words: hypnosis, crime, irresponsibility, physical coercion, method of committing crime

\section{Aspecte introductive.}

Atât în legislația penală a Republicii Moldova, cât și în teoria dreptului penal, starea de hipnoză este prea puțin analizată, fapt care naște multiple discuții privind aprecierea corectă a acesteia în perspectiva juridico-penală.

Actualmente, în rezultatul dezvoltării unor domenii, precum neuropsihologia și hipnologia, sunt identificate tot mai multe metode de influențare asupra creierului uman. Constatăm cu regret faptul, că 
descoperirile care se fac în scopuri medicale sunt tot mai des utilizate în scopuri criminale.

Prin „hipnoză” se înțelege starea asemănătoare cu somnul sau cu somnambulismul, provocată artificial prin sugestie, în timpul căreia controlul conştient asupra propriului comportament și contactul cu realitatea slăbește, acțiunile celui hipnotizat fiind supuse voinței hipnotizatorului. ${ }^{1}$

Așa numita „hipnoza criminală”, având la bază definiția generală a stării de hipnoză, necesită o definiție separată, legislația penală actuală a omis acest aspect. Prin hipnoza criminală, în doctrina dreptului penal, se înțelege aducerea intenționată şi ilegală a persoanei în stare de neputință (hipnoză) împotriva voinței acesteia prin influențarea asupra psihicului acesteia în scopurile criminale ${ }^{2}$.

Observăm că, hipnotizarea persoanei privită sub aspectul juridicopenal, poate fi utilizată de către infractor atât pentru a săvârși infracțiunea cu „mâinile” unei alte persoane, cât și pentru a-și ușura realizarea infracțiunii, lipsind persoana de posibilitatea de a opune rezistență. În cele ce urmează, vom analiza ambele ipoteze.

II. Infracțiunea săvârșită de către o persoană hipnotizată. Încadrarea juridico-penală.

Dat fiind faptul, că la momentul actual domeniul neuropsihologiei și hipnologiei se dezvoltă tot mai activ, metodele şi practicile de hipnotizare a

\footnotetext{
${ }^{1}$ A se vedea definiția furnizată de: $\underline{\mathrm{https}}$ //dexonline.ro/definitie/hipnoz\%C4\%83.

2 D.A. SEmenova Gipnoz kak vid psihiceskogo prinujdeniia v ugolovnom prave. (Hipnoza ca modalitatea constrângerii psihice în dreptul penal). Vestnik Iugorskogo gosudarstvennogo universiteta, 2015, p. 45-46.
} 
persoanei devin tot mai accesibile. Astfel, devine tot mai posibilă ipoteza comiterii infracțiunilor prin inducerea persoanei în stare de hipnoză, utilizând ulterior această stare a ei în scopuri criminale. Aceasta se datorează şi faptului că descoperirea unei astfel de fapte reprezintă un proces mult mai dificil în raport cu descoperirea unei infracțiuni comise în mod obișnuit. Astfel, infracțiunii comise de către o persoană hipnotizată îi sunt caracteristice unele neclarități, mai ales sub aspectul calificării faptelor comise de persoana în stare de hipnoză şi tragerea ulterioară la răspundere penală a acesteia.

$\mathrm{Cu}$ toate că teoria dreptului penal este destul de restrânsă în ceea ce privește abordarea temei respective, totuşi au fost formulate unele aspecte referitoare la răspunderea persoanei care comite o infracțiune aflându-se în stare de hipnoză. Comună, pentru toate punctele de vedere, este opinia conform căreia persoana care a săvârșit o infracțiune în stare de hipnoză urmează a fi liberată de răspundere penală. Atunci, apare fireasca întrebare, care ar fi temeiul liberării de răspundere penală a acesteia? În teorie au fost formulate două opinii diferite, pe care le vom analiza.

Conform primei teze enunțate în doctrina penală, starea de hipnoză este atribuită uneia din formele de iresponsabilitate. Astfel, susținătorii acestei teorii, printre care este și renumitul savantul rus N. Taganțev, afirmă că, principiile generale pe care se bazează noțiunile de infracțiune și pedeapsă penală, de responsabilitate şi iresponsabilitate se răspândesc şi asupra stării de hipnoză, atribuind acesteia calitatea de formă de manifestare a stării de iresponsabilitate. Se consideră că, dacă persoana a acționat sub imperiul stării de hipnoză, astfel de acțiuni trebuie privite ca fiind comise inconștient, fără aşi realiza caracterul celor comise şi fiind lipsit de posibilitatea de a-şi dirija 
acțiunile, deci trebuie să fie recunoscute ca săvârșite în stare de iresponsabilitate 3 .

$\mathrm{Cu}$ toate că teza dată are o anumită bază argumentativă, reieșind din abordarea juridico-penală a stării de iresponsabilitate, atribuirea stării de hipnoză la această stare este inacceptabilă. Starea de iresponsabilitate în dreptul penal al Republicii Moldova presupune că persoana, în timpul comiterii infracțiunii, în timpul săvârşirii unei fapte prejudiciabile, nu putea să-şi dea seama de acțiunile ori inacțiunile sale sau nu putea să le dirijeze din cauza unei boli psihice cronice, a unei tulburări psihice temporare sau a altei stări patologice. ${ }^{4}$ Astfel, cu toate că criteriul juridic al stării de iresponsabilitate, şi anume, imposibilitatea de a conştientiza caracterul infracțional al faptei sale sau imposibilitatea de a-și dirija acțiunile/inacțiunile, este aferent stării de hipnoză, se atestă lipsa criteriului medical al iresponsabilității, care se exprimă prin prezența unei boli psihice cronice, a unei tulburări psihice temporare sau a unei alte stări patologice. Aceasta se datorează faptului că hipnoza nu poate fi privită ca o stare psihică patologică, fiind o stare deosebită a psihicului, or starea patologică este cea provocată de o boalăs.

A două teorie, susținută de cercetătorii stării de hipnoză sub aspectul juridico-penal, se axează pe faptul atribuirii acesteia unei forme de constrângere psihică, prin intermediul căreia hipnotizatorul „impune” persoanei, împotriva voinței acesteia, să comită o infracțiune. Însă nici

3 N. TAGantsev, Russkoe ugolovnoie pravo. Lectsii. Chasti Obshchaia. (Dreptul penal rusesc. Partea generală.) Nauka, 1994, p. 175.

4 Codul penal al Republicii Moldova din 18.04.2002.

https://www.legis.md/cautare/getResults?doc id=109495\&lang=ro (accesat la 05.05.2020). 5 https://dexonline.ro/definitie/patologic (accesat la 16.06.2020). 
această teorie nu este perfectă, reieșind din faptul că legislația penală a Republicii Moldova nu conține o definiție clară a constrângerii, definiția fiind una destul de vastă. Astfel, Codul penal al Republicii Moldova prevede, în art.39, că nu constituie infracțiune fapta, prevăzută de legea penală, care a cauzat daune intereselor ocrotite de lege ca rezultat al constrângerii fizice sau psihice, dacă în urma acestei constrângeri persoana nu putea să-şi dirijeze acțiunile ${ }^{6}$. Din această formulare, reiese clar doar faptul că prezența constrângerii psihice liberează persoana de răspundere penală, fără a da explicații asupra a ce anume reprezintă constrângerea psihică. Astfel, părerile enunțate în doctrină au un caracter controversat. Unii definesc constrângerea ca influențarea violentă asupra unei persoane cu scopul de o impune să comită oarecare acțiuni împotriva voinței sale7. Atribuind constrângerii psihice sensul dat, în acest concept se includ formele de exteriorizare a acesteia, precum amenințare cu caracter diferit, șantaj și alte forme asemănătoare, prin care făptuitorul pune persoana în stare de imposibilitate de a-și exprima liberă voința, astfel persoana este nevoită să acționeze în felul impus de făptuitor, păstrând conştiința asupra acțiunilor sale. Deci persoana, în urma influențării, pierde posibilitatea de a alege modul în care acționează. Majoritatea definițiilor constrângerii psihice scot în evidență influențarea asupra persoanei constrânse psihic prin metode violente, cum ar fi amenințarea cu omor, cu vătămarea gravă a persoanei respective nemijlocit ori a membrilor de familie ale acesteia, ceea ce este departe de natura hipnozei. Natura hipnozei constă în influența deosebită asupra conștiinței

\footnotetext{
${ }^{6}$ Codul penal al Republicii Moldova din 18.04.2002.

https://www.legis.md/cautare/getResults?doc id=109495\&lang=ro (accesat la 05.05.2020)

7 V. KALUGHIN Fizicheskoe ili psihicheskoe prinuzhdenie kak obstoiatelstvo, iskliuchaiushchee prestupnost deianiia. (Constrângerea fizică sau psihică-cauza care înlătură caracterul penal al faptei). Moskva, 2001, p. 10.
} 
persoanei, prin intermediul impunerii intenției sale criminale unei alte persoane împotriva voinței acesteia. Astfel, hipnoza nu se încadrează în tratarea clasică a noțiunii de constrângere psihică, reieșind din opinia că, sub constrângere psihică persoana totuși iş̦i păstrează capacitatea de a-şi dirija acțiunile şi de a-și da seamă despre caracterul celor săvârşite, pe când hipnoza o lipsește de această capacitate.

Astfel, considerăm că nu ar fi corect să atribuim starea de hipnoză unei forme ale constrângerii psihice, cu toate că acest lucru este posibil, dat fiind faptul că definiția legală a constrângerii psihice, în Codul penal al Republicii Moldova, este una foarte vastă şi poate include, în sine, şi starea de hipnoză. Unele state includ, în termenul de constrângere, utilizarea hipnozei sau a unor substanțe toxice/narcotice. Astfel, nu ar exista probleme la interpretarea normei şi ar fi evitată aplicarea neuniformă a acesteia.

Cum am menționat anterior, comun pentru ambele teorii este faptul că se susține necesitatea liberării de răspundere penală a persoanei care a comis infracțiunea în stare de hipnoză. Însă, considerăm că pot exista anumite situații în care este posibilă tragerea la răspundere penală a unei persoane ce a săvârşit infracțiunea în stare de hipnoză. Astfel, criteriul determinant, care atestă necesitatea tragerii persoanei hipnotizate la răspundere penală, este nivelul conştiinței neafectate de influența hipnozei. Dacă persoana, în urma inducerii sale în stare de hipnoză, îşi păstrează un nivel anumit de conștiință, ce îi permite să-şi dirijeze acțiunile și să-şi dea seama de cele săvârşite, nu ar exista temei pentru liberarea acesteia de răspundere, deoarece a existat posibilitatea de a renunța la comiterea infracțiunii. 
La fel, părerea susținută şi de către profesorul Streteanu' ${ }^{8}$, în România, dar și de teoreticienii ruși Ceceli G. Și Sedîh L. ${ }^{9}$, va fi aplicată răspunderea penală față de persoana care a comis infracțiune fiind în stare de hipnoză, dacă această stare a fost provocată la rugămintea subiectului, având, din start, un scop criminal la bază. În acest caz, deși în timpul comiterii infracțiunii persoana, aflându-se în stare de hipnoză, nu-şi realiza caracterul acțiunilor sale și nu putea să-și dirijeze acțiunile, autorul va răspunde penal, dat fiind faptul că, la momentul provocării acestei stări, capacitatea intelectivă și cea volitivă erau prezente ${ }^{10}$, infracțiunea fiind una dorită şi intenționată.

Deci, persoana nu trebuie să fie supusă răspunderii penale, dacă aceasta nu ştia despre scopul criminal al inducerii sale în stare de hipnoză, nu avea nici o posibilitate de a opune rezistență şi de a se împotrivi faptelor hipnotizatorului și nu a putut dirija faptele sale.

III. Infracțiunea săvârșită asupra unei persoane hipnotizate. Aspecte de calificare.

Cu privire la calificarea unei infracțiuni săvârșite asupra unei persoane hipnotizate, menționăm că starea de hipnoză, fiind o stare care lipsește persoana de posibilitatea de a-şi exprima voința, inducând-o într-o stare de neputință de a opune rezistență făptuitorului, în teoria dreptului penal se încadrează în prevederile care agravează răspunderea penală pentru

\footnotetext{
${ }^{8}$ F. STRETEAnU, D. Nițu. Drept penal: partea generală, București, 2014, p. 424.

9 G. CHechel, L. SEDYH Osobennosti kvalificatsii prestupleniia, sovershennogo zagipnotizirovannym litsom. (Particularitățile calificării infracțiunilor, comise de către o persoană hipnotizată). Moskva, 2009, p.54-57

${ }^{10}$ F. STRETEANU, D. Nițu. Drept penal: partea generală. București, 2014, p. 425.
} 
profitarea de starea de neputință cunoscută sau evidentă a victimei. Legislația penală a Republicii Moldova atribuie, la temeiurile stării de neputință, vârsta înaintată, boala, dizabilitatea sau alt factor. Astfel, starea de hipnoză poate fi încadrată în noțiunea de „alt factor” care generează starea de neputință a victimei.

$\mathrm{Cu}$ toate că totul pare a fi clar, sunt totuși unele aspecte care credem că sunt necesare a fi abordate întru analiza mai amplă a acestei întrebări.

Atribuirea stării de hipnoză la starea de neputință în mare parte depinde de gradul de intensitate a hipnozei şi de reacţia individuală a persoanei în condițiile acestei stări. Aceasta se explică prin faptul că psihicul fiecărei persoane este diferit, deci o persoană poate fi indusă în stare de hipnoză mai ușor în raport cu alta, astfel făptuitorul nu poate să prevadă în totalitate cum va influența starea de hipnoză psihicul persoanei asupra căreia se săvârșeşte o infracțiune. Astfel, dacă persoana este sub imperiul hipnozei, însă este păstrată conștiința acesteia și posibilitatea de dirijare a acțiunilor sale (spre exemplu, starea de credulitate) nu putem atribui astfel de stare la cea de neputință.

Deci, pentru a reține starea de neputință provocată de hipnoză, gradul acesteia trebuie să corespundă fazei ce o lipsește pe persoană de posibilitatea de a opune rezistență făptuitorului.

\section{Concluzii și recomandări.}

În urma analizei stării de hipnoză sub aspectul juridico-penal am reușit să formulăm următoarele concluzii:

1. Persoana care comite o infracțiune în stare de hipnoză nu poate răspunde penal, în condițiile în care nu a avut posibilitatea să conştientizeze 
caracterul acțiunilor sale şi nu le putea dirija. În sensul dat, sub aspect juridico-penal, este necesar un cadru legal adecvat, care ar permite încadrarea juridică corectă și precisă a stării de hipnoză, prezentă în momentul comiterii de către persoană a unei infracțiuni. Pentru rezolvarea acestei probleme, propunem următoare variantă de completare a legii penale a Republicii Moldova, şi anume:

Completarea articolului ce reglementează norma privind constrângerea fizică și psihică, în calitate de cauze care înlătură caracterul penal al faptei, cu un alineat distins care va atribui stării de hipnoză o formă specifică a constrângerii psihice cu următorul conținut: „Se atribuie la categoria de formă specifică a constrângerii psihice starea de hipnoză, în urma căreia persoana nu deține capacitatea de a conştientiza caracterul acțiunilor sale și de a le dirija”. Considerăm că această reglementare este necesară pentru evitarea interpretării neuniforme a definiției constrângerii psihice în Codul penal al Republicii Moldova care este una destul de vastă. În cazul constrângerii psihice, persoana își păstrează capacitatea de a-şi dirija acţiunile şi de a-şi dea seama de caracterul celor săvârşite însă, în urma influențării efectuate asupra ei, își pierde libertatea de a-şi exprima voința referitor la conduita aleasă. Hipnoza este totuşi, în opinia noastră, o formă deosebită a constrângerii psihice.

2. În cazul infracțiunii comise asupra unei persoane hipnotizate, calificarea acesteia cu agravarea răspunderii pentru aflarea victimei în stare de neputință, depinde de măsura în care psihicul victimei a fost influențat de hipnoză, lipsind-o de posibilitatea de a opune rezistență. Doar acea stare în care persoana a fost lipsită în totalitate de posibilitatea opunerii rezistenței poate agrava răspunderea penală. 